Nadya Febylia, Gregorius Genep Sukendro: Digitalisasi Komunikasi Penggiat Backpacker (Studi Kasus terhadap Komunitas Backpacker)

\title{
Digitalisasi Komunikasi Penggiat Backpacker (Studi Kasus terhadap Komunitas Backpacker)
}

\author{
Nadya Febylia, Gregorius Genep Sukendro \\ nadyafebylia1@gmail.com,geneps@fikom.untar.ac.id \\ Fakultas Ilmu Komunikasi Universitas Tarumanagara
}

\begin{abstract}
Along with the times, technology is something that we often encounter around us, including in the world of backpackers. In this digital era, backpakers are divided into two types, namely backpackers who use traveling applications and backpakers who don't. This study aims to determine the positive and negative impacts of digitizing communication on backpacker activists. The formulation of the problem is to determine the positive and negative impacts of new media on the backpacker community, therefore researchers will conduct research on the Jakarta backpacker community. Therefore, the researcher wanted to examine the impact resulting from the use of digital media on the backpacker community by using a qualitative descriptive method and using a phenomenological approach to find out firsthand the experiences of backpacker activists, the research location through zoom from their respective homes. From the results of the research that the researchers have done, the researcher can draw the conclusion that the use of technology in the backpaker world is more positive because the informants whom the researchers interviewed through zoom felt very helped by the current travel applications.
\end{abstract}

Keywords: Backpacker, Impact, Technology, Technopacker

\begin{abstract}
Abstrak
Seiring dengan perkembangan zaman, teknologi merupakan sesuatu hal yang sering kita jumpai disekitar kita, termasuk dalam dunia backpacker. Pada era digital ini, backpaker dibagi menjadi dua tipe yaitu backpacker yang menggunakan aplikasi perjalanan dan backpaker yang tidak menggunakan aplikasi. Penelitian ini bertujuan untuk mengetahui dampak positif dan dampak negatif dari digitalisasi komunikasi terhadap penggiat backpacker. Penelitian ini ingin mengetahui dampak positif dan dampak negatif dari media baru yang masuk dalam komunitas backpacker. Peneliti melakukan penelitian terhadap komunitas backpacker Jakarta. Peneliti ingin meneliti tentang dampak yang dihasilkan dari penggunaan media digital terhadap komunitas backpacker dengan menggunakan metode deskriptif kualitatif dan menggunakan pendekatan fenomenologi untuk mengetahui secara langsung pengalaman yang dilakukan oleh para penggiat backpacker. Teknik pengumpulan data dilakukan dengan wawancara online melalui sarana Zoom. Dari hasil penelitian ditemukan bahwa penggunaan teknologi pada dunia backpaker lebih mengarah pada hal yang positif karena informan sangat terbantu dengan aplikasi perjalanan yang ada saat ini.
\end{abstract}

Kata Kunci: Backpacker, Dampak, Technopacker, Teknologi

\section{Pendahuluan}

Teknologi komunikasi dan informasi juga mempengaruhi industri pariwisata di Indonesia, karena teknologi komunikasi mempermudah wisatawan baik dalam negeri maupun luar negeri untuk mengetahui informasi-informasi wisata yang akan dituju dengan menggunakan media komunikasi internet seperti Instagram, Facebook, 
YouTube, maupun sarana teknologi berbasis pelayanan jasa dan akomodasi seperti Traveloka, Agoda dan lain sebagainya yang dapat mempermudah para wisatawan untuk berpergian dan mengunjungi lokasi yang akan dituju. Seperti diketahui industri pariwisata sangat berkembang pesat dan diminati oleh masyarakat baik wisata dalam negeri maupun mencanegara, karena pariwisata sendiri merupakan suatu perjalanan yang dilakukan untuk rekreasi atau liburan yang banyak diminati oleh semua kalangan oleh karena itu maka banyak orang yang memiliki hobi yang sama membuat beberapa komunitas, dan salah satunya merupakan komunitas backpacker (Kadir, 2003:2).

Backpack sendiri merupakan Bahasa Inggris yang artinya tas yang digendong di belakang. Wisata beransel backpacking adalah perjalanan ke suatu tempat tanpa membawa barang barang yang memberatkan atau membawa koper, Adapun barang bawaan hanya berupa tas yang digendong, pakaian secukupnya dan perlengkapan yang diperlukan, biasanya backpacker yang melakukan perjalanan seperti ini adalah dari kalangan berusia muda maupun dewasa, tidak perlu tidur di hotel tapi cukup di suatu tempat yang dapat dijadikan untuk tempat beristirahat. Perjalanan seperti ini dilakukan di dalam negeri ataupun luar negeri. Forum-forum backpacker seperti inilah yang sekarang banyak diminati oleh orang orang yang menyebut dirinya pecinta alam, penikmat keindahan, petualangan dan lain lain (Majstrovic, 2011).

Penelitian ini ingin mengetahui dampak positif dan dampak negatif dari media baru yang masuk dalam komunitas backpacker. Peneliti melakukan penelitian terhadap komunitas "backpacker Jakarta" dan "Muslim Backpacker Jakarta". Backpacker Jakarta merupakan komunitas pecinta alam yang mengkoordinir anggota komunitasnya menggunakan jejaring sosial Instagram sebagai metode utamanya. Backpacker Jakarta juga memiliki akun Youtube mengenai kegiatan komunitas saat melakukan acara pariwisata. Backpacker Jakarta sendiri merupakan backpacker yang sudah menggunakan media digital dan aplikasi digital sebagai sarana utama dalam melakukan perjalanan. Backpacker Jakarta merupakan komunitas pertama backpacker di daerah Jakarta yang anggotanya tidak harus dari daerah Jakarta juga melainkan dari seluruh daerah, untuk bergabung dengan komunitas mereka tidak memungut biaya namun terdapat uang iuran sebesar 250 ribu rupiah setiap minggunya untuk membantu anggaran saat berpergian.

Muslim Backpacker Jakarta merupakan komunitas pecinta alam yang membuka komunitasnya awalnya hanya untuk perjalanan ketempat tempat wisata sejarah islam, namun karena anggota yang semakin bertambah membuat perjalanannya tidak hanya untuk ketempat tempat sejarah melainkan keberbagai lokasi namun tetap menggunakan syariat islam, Muslim Backpacker sendiri masih menggunakan cara lama dalam perjalanan yaitu dengan memberhentikan mobil dan mencari tumpangan untuk melakukan perjalanan.

\section{Metode Penelitian}

Peneliti melakukan penelitian dengan pendekatan fenomenologi untuk mengetahui dampak budaya digitalisasi terhadap para penggiat backpacker dan para backpacker yang tidak terkena digitalisasi, untuk mengetahui seberapa dampak yang dihasilkan maka diperlukannya pengambilan data secara langsung terhadap dua backpacker yang berbeda. Pengambilan data melalui wawancara, observasi dan dokumentasi. Untuk melakukan wawancara dan observasi dibuat panduan 
Nadya Febylia, Gregorius Genep Sukendro: Digitalisasi Komunikasi Penggiat Backpacker (Studi Kasus terhadap Komunitas Backpacker)

wawancara dan observasi mengenai dampak digitalisasi komunikasi terhadap para penggiat backpacker.

Subyek penelitian adalah backpacker. Peneliti melakukan wawancara pada empat narasumber yaitu:

Tabel 3.2 Daftar Narasumber

\begin{tabular}{|c|c|c|c|c|c|}
\hline No & Nama & $\begin{array}{c}\text { Jenis } \\
\text { Kelamin } \\
(\mathbf{P} / \mathbf{L})\end{array}$ & Keterangan Jabatan & Umur & Pekerjaan \\
\hline $\mathbf{1}$ & Muhammad Fadil & L & Humas Backpacker Jakarta & $\mathbf{2 6}$ th & Videographer \\
\hline $\mathbf{2}$ & Jordan Wattimera & L & Admin 1 Backpacker Jakarta & $\mathbf{2 9}$ th & $\begin{array}{c}\text { Karyawan } \\
\text { Swasta }\end{array}$ \\
\hline $\mathbf{3}$ & Bala Putera & L & Wakil Ketua Muslim Backpacker Jakarta & $\mathbf{2 4}$ th & Mahasiswa \\
\hline $\mathbf{4}$ & Naura Salsabila & P & $\begin{array}{r}\text { Admin Media Sosial Muslim Backpacker } \\
\text { Jakarta }\end{array}$ & $\mathbf{2 3}$ th & Mahasiswa \\
\hline
\end{tabular}

Sumber: Dokumentasi peneliti

Objek penelitian dalam penelitian kualitatif menurut Spradley dinamakan situasi sosial, yang terdiri dari tiga komponen yaitu place (tempat), actor (pelaku), dan activities (aktifitas) (Sugiono,229:2012). Dalam penelitian ini yang menjadi objek penelitian ini adalah penggunaan media online dan aplikasi yang mempermudah para backpacker dalam berpergian dan meneliti backpacker yang tidak menggunakan media online dan aplikasi. Penelitian terutama fokus pada komunitas "Backpacker Jakarta" dan "Muslim Backpacker Jakarta".

Komunitas "Backpacker Jakarta" merupakan komunitas yang paling aktif dalam menggunakan media digital sebagai sarana mempromosikan komunitasnya di media sosial dan menggunakan aplikasi penyedia jasa sebagai sarana untuk melakukan perjalanan pariwisata. Sementara, pemilihan "Muslim Backpacker Jakarta" karena komunitas ini menghindari penggunaan media digital dan menganut faham agama yang sangat kental berbeda dengan komunitas backpacker pada umumnya.

Menurut Sugiyono, dalam penelitian kualitatif, Teknik pengumpulan data yang utama adalah observasi participant, wawancara mendalam studi dokumentasi, dan gabungan ketiganya atau triagulasi (Sugiyono, 229:2012). Peneliti menggunakan wawancara tak berstruktur. Peneliti akan mengajukam berbagai pertanyaan sesuai dengan tujuan penelitian yaitu tentang dampak digitalisasi bagi penggiat backpacker dan penelitian pada backpacker yang tidak menggunakan digitalisasi. Peneliti juga melakukan observasi terus terang atau tersamar.

Dalam hal ini, peneliti melakukan pengumpulan data menyatakan terus terang kepada sumber data, bahwa peneliti sedang melakukan penelitian (Sugiyono, 145:2012). Data sekunder adalah data yang diperoleh dari sumber kedua atau sumber sekunder. Peneliti menggunakan data yang diperoleh dari kepustakaan (literature) serta mempelajari buku-buku referensi, sumber-sumber internet yang berkaitan dengan judul untuk mendapatkan informasi yang relevan (Kriyantono, 42:2012). 


\section{Hasil Temuan Dan Diskusi}

Tabel 4.1 Hasil Penelitian

\begin{tabular}{|c|c|c|c|c|}
\hline \multirow[b]{2}{*}{ No } & \multirow[b]{2}{*}{ Pertanyaan } & \multicolumn{2}{|c|}{ Informan } & \multirow[b]{2}{*}{ Jawaban } \\
\hline & & $\begin{array}{c}\text { Backpacker } \\
\text { Jakarta }\end{array}$ & $\begin{array}{c}\text { Muslim } \\
\text { Backpacker } \\
\text { Jakarta }\end{array}$ & \\
\hline \multirow[b]{2}{*}{1} & \multirow{2}{*}{$\begin{array}{c}\text { Apa alasan } \\
\text { komunitas } \\
\text { anda } \\
\text { menggunakan } \\
\text { media digital } \\
\text { sebagai } \\
\text { sarana } \\
\text { berpariwisata } \\
?\end{array}$} & Informan 1 & & $\begin{array}{l}\text { karena dengan adanya media digital } \\
\text { saat ini mempermudah kami dalam } \\
\text { mengetahui tiket penerbangan, tiket } \\
\text { bus atau kereta dan booking hotel }\end{array}$ \\
\hline & & Informan 2 & & $\begin{array}{l}\text { ya belum lagi kalau kami tersesat } \\
\text { masih ada google maps untuk } \\
\text { nunjukin jalan yang benar yang harus } \\
\text { kita lewati, google maps lebih mudah } \\
\text { dari pada harus lihat kompas yang } \\
\text { kadang membuat kita kebingungan } \\
\text { juga karena harus lihat arah angina }\end{array}$ \\
\hline \multirow[t]{2}{*}{2} & \multirow[t]{2}{*}{$\begin{array}{c}\text { Apakah } \\
\text { aplikasi yang } \\
\text { biasanya } \\
\text { digunakan } \\
\text { untuk } \\
\text { melakukan } \\
\text { perjalanan } \\
\text { pariwisata }\end{array}$} & Informan 1 & & $\begin{array}{l}\text { aplikasi yang biasa kita pakai yaitu } \\
\text { Waze, Google Maps, Agoda, } \\
\text { Traveloka, dan yang paling penting } \\
\text { yaitu aplikasi Splitwise yaitu aplikasi } \\
\text { keuangan yang kita pakai kalau } \\
\text { berpergian jadi mempermudah kita } \\
\text { mengatur uang kas anggota untuk } \\
\text { melakukan perjalanan ke suatu } \\
\text { daerah, berapa biaya yang } \\
\text { dikeluarkan, transportasi yang kita } \\
\text { gunakan, setelah kepulangan pun } \\
\text { masih bisa dihitung jadi biaya pulang } \\
\text { dan berangkat kita semua masukan } \\
\text { kedalam splitwise, semua aplikasi itu } \\
\text { sangat membantu kita dalam } \\
\text { melakukan berpajalanan }\end{array}$ \\
\hline & & Informan 2 & & $\begin{array}{l}\text { selain aplikasi kita juga menggunakan } \\
\text { media sosial sebagai sarana untuk } \\
\text { memberikan informasi kepada para } \\
\text { pecinta alam yang belum masuk ke } \\
\text { komunitas backpacker }\end{array}$ \\
\hline \multirow[t]{2}{*}{3} & \multirow{2}{*}{$\begin{array}{c}\text { Apakah } \\
\text { dengan } \\
\text { menggunakan } \\
\text { aplikasi } \\
\text { tersebut dapat } \\
\text { mengurangi } \\
\text { biaya } \\
\text { pengeluaran } \\
\text { saat } \\
\text { berpergian }\end{array}$} & Informan 1 & & $\begin{array}{l}\text { sejauh ini kami sangat tertolong } \\
\text { dengan adanya aplikasi akomodasi } \\
\text { tersebut karena terdapat banyak sekali } \\
\text { promo, apalagi kalau group besar } \\
\text { seperti kami jadi dapat discount } \\
\text { cukup besar juga bisa sampai } 10 \% \\
\text { hematnya }\end{array}$ \\
\hline & & Informan 2 & & $\begin{array}{l}\text { kita juga menggunakan aplikasi } \\
\text { splitwise jadi kita dapat tahu } \\
\text { pengeluaran kita dari saat berangkat } \\
\text { sampai dengan pulang, apalagi lagi } \\
\text { wabah seperti ini jadi lebih banyak } \\
\text { promo, seperti kemarin promo air }\end{array}$ \\
\hline
\end{tabular}




\begin{tabular}{|c|c|c|c|}
\hline & & & $\begin{array}{l}\text { Asia jadi cuman bayar } 10 \text { ribu saja } \\
\text { sudah bisa pergi kemana-mana }\end{array}$ \\
\hline \multirow[t]{2}{*}{4} & \multirow[t]{2}{*}{$\begin{array}{c}\text { Apa dampak } \\
\text { negatif media } \\
\text { digital bagi } \\
\text { komunitas } \\
\text { backpacker } \\
\text { Jakarta }\end{array}$} & Informan 1 & $\begin{array}{l}\text { Sebenarnya dampak dari penggunaan } \\
\text { media digital sendiri tidak banyak } \\
\text { hanya sebagian kecil dan tidak terlalu } \\
\text { menjadi masalah bagi kami. } \\
\text { Dampaknya sendiri yaitu kami jadi } \\
\text { terlalu bergantung dengan aplikasi } \\
\text { dan media sosial untuk sarana kita } \\
\text { dalam mempermudah perjalanan, dan } \\
\text { juga waktu untuk ngobrol bersama } \\
\text { jadi kurang leluasa karena anak-anak } \\
\text { banyak yang update status di } \\
\text { Instagram, bahkan buat video vlog, } \\
\text { tapi ya itu kan buat informasi juga } \\
\text { buat para pecinta alam yang lainnya } \\
\text { betapa serunya pergi pariwisata } \\
\text { ramai-ramai dengan biaya yang } \\
\text { murah }\end{array}$ \\
\hline & & Informan 2 & $\begin{array}{l}\text { Dampak dari penggunaan media } \\
\text { digital buat saya dan teman-teman ya } \\
\text { mungkin kita kadang fokus untuk } \\
\text { update story di Instagram aja sih } \\
\text { cuman itu kalau di atas masih ada } \\
\text { signal kalo engga sih oke-oke aja, } \\
\text { selebihnya tidak ada dampak yang } \\
\text { signifikan }\end{array}$ \\
\hline \multirow[t]{2}{*}{5} & \multirow[t]{2}{*}{$\begin{array}{l}\text { Apa dampak } \\
\text { positif dari } \\
\text { penggunaan } \\
\text { media digital } \\
\text { terhadap } \\
\text { komunitas } \\
\text { backpacker }\end{array}$} & Informan 1 & $\begin{array}{l}\text { Menurut saya dampak positif yang } \\
\text { kami dapatkan dari media digital } \\
\text { seperti aplikasi dan media sosial yaitu } \\
\text { yang pertama media sosial membantu } \\
\text { kami dalam memberikan informasi } \\
\text { kepada para pecinta alam, menjadi } \\
\text { sarana untuk berkomunikasi satu } \\
\text { dengan yang lainnya, menjadi sarana } \\
\text { untuk mengenal lebih dekat tanpa } \\
\text { harus ketemu, bisa video call group } \\
\text { Whatsapp, dan juga untuk aplikasi } \\
\text { sendiri juga memiliki dampak positif } \\
\text { yaitu mempermudah kami dalam } \\
\text { mengetahui jadwal keberangkatan, } \\
\text { mengetahui penginapan dengan harga } \\
\text { yang murah dan kosong, dan masih } \\
\text { banyak lagi dampak positif yang kami } \\
\text { dapatkan }\end{array}$ \\
\hline & & Informan 2 & $\begin{array}{l}\text { dampak positif dari penggunaan } \\
\text { aplikasi dan media sosial yaitu } \\
\text { banyak sekali ya, dampaknya bagi } \\
\text { kita jadi kita bisa dengan mudah } \\
\text { koordinasi anak-anak komunitas } \\
\text { kasih tahu kalau nanti ada event, atau } \\
\text { kapan mau pergi dirundingin dulu } \\
\text { waktu yang pas ya pakai Whatsapp, } \\
\text { Instagram juga kita di situ share }\end{array}$ \\
\hline
\end{tabular}




\begin{tabular}{|c|c|c|c|}
\hline & & & $\begin{array}{l}\text { kesibukan kita pergi kemana aja, jadi } \\
\text { anggota yang belum bergabung tahu } \\
\text { keseruan komunitas kita, untuk } \\
\text { aplikasinya sendiri ya kita bisa tahu } \\
\text { promo-promo yang ada, terus kalo } \\
\text { mau pergi tidak usah ribet untuk cari } \\
\text { tumpangan karena group kita banyak } \\
\text { anggotanya itu malah nyusahin } \\
\text { masyarakat sekitar, jadi kita kalau } \\
\text { pakai aplikasi ya enak aja tidak usah } \\
\text { nyusahin masyarakat sekitar }\end{array}$ \\
\hline \multirow[t]{2}{*}{6} & \multirow[t]{2}{*}{$\begin{array}{l}\text { Apa alasan } \\
\text { komunitas } \\
\text { anda tidak } \\
\text { terpengaruh } \\
\text { jaman untuk } \\
\text { menggunakan } \\
\text { media digital } \\
\text { sebagai } \\
\text { sarana } \\
\text { akomodasi }\end{array}$} & Informan 3 & $\begin{array}{l}\text { komunitas kami masih menggunakan } \\
\text { cara lama sebenarnya memiliki alasan } \\
\text { tersendiri yaitu kami ingin perjalanan } \\
\text { kami itu benar-benar selain dekat } \\
\text { dengan alam, kita juga mendekatkan } \\
\text { diri pada Tuhan dengan tidak } \\
\text { menggunakan ponsel dan alat } \\
\text { komunikasi lainnya membuat kami } \\
\text { lebih dekat dengan keduanya, } \\
\text { keseruan dan kedekatan yang kami } \\
\text { dapatkan juga lebih banyak }\end{array}$ \\
\hline & & Informan 4 & $\begin{array}{l}\text { Dengan menggunakan cara lama, } \\
\text { menjadi lebih estetik dan lebih seru } \\
\text { seperti semua merasakan susah } \\
\text { senang bersama }\end{array}$ \\
\hline \multirow[b]{2}{*}{7} & \multirow[b]{2}{*}{$\begin{array}{l}\text { Apa pendapat } \\
\text { anda } \\
\text { mengenai } \\
\text { penggunaan } \\
\text { media digital } \\
\text { bagi penggiat } \\
\text { backpacker }\end{array}$} & Informan 3 & $\begin{array}{l}\text { Menurut saya penggunaan media } \\
\text { digital itu wajar saja, semua terserah } \\
\text { mereka, dan bagaimana mereka } \\
\text { menyikapinya, namun yang namanya } \\
\text { backpacker dari dulu kan tidak } \\
\text { menggunakan media digital }\end{array}$ \\
\hline & & Informan 3 & $\begin{array}{l}\text { Sekarang sih banyak sekali yang } \\
\text { memakai media digital karena } \\
\text { mengikuti perkembangan jaman juga } \\
\text { kan, mungkin banyak juga } \\
\text { manfaatnya menggunakan media } \\
\text { digital, tetapi kalau kami sih } \\
\text { menggunakan media sosial cuman } \\
\text { saat koordinasi aja selebihnya waktu } \\
\text { sudah mau pergi semua alat } \\
\text { komunikasi disimpan oleh panitia, } \\
\text { tapi beberapa regu sih selalu bawa } \\
\text { kamera untuk dokumentasi untuk di } \\
\text { upload di facebook tapi itu juga } \\
\text { jarang sih }\end{array}$ \\
\hline 8 & $\begin{array}{l}\text { Apakah tanpa } \\
\text { adanya } \\
\text { aplikasi } \\
\text { akomodasi } \\
\text { dapat } \\
\text { menghemat } \\
\text { pengeluaran }\end{array}$ & Informan 3 & $\begin{array}{l}\text { Pastinya anggaran yang kita } \\
\text { keluarkan juga tidak sebanyak } \\
\text { mereka yang menggunakan aplikasi, } \\
\text { karena kami tidak perlu membeli tiket } \\
\text { untuk pesan kursi bus, kereta, atau } \\
\text { pesawat karena kita cuman numpang } \\
\text { sama angkutan yang lewat atau truk- }\end{array}$ \\
\hline
\end{tabular}




\begin{tabular}{|c|c|c|c|}
\hline & \multirow[t]{2}{*}{$\begin{array}{c}\text { anda saat } \\
\text { melakukan } \\
\text { pariwisata }\end{array}$} & & $\begin{array}{l}\text { truk yang ada karena anggota kami } \\
\text { yang ikut juga lumayan banyak, kita } \\
\text { mengeluarkan uang secukupnya } \\
\text { paling untuk membeli makan sama } \\
\text { perlengkapan untuk mandi saja, } \\
\text { selebihnya tidak mengeluarkan biaya } \\
\text { apa-apa biasanya kita cukup } \\
\text { membawa uang } 200 \text { ribu karena kita } \\
\text { juga ada kas anggota untuk keadaan } \\
\text { darurat }\end{array}$ \\
\hline & & Informan 4 & $\begin{array}{l}\text { Anggaran yang dikeluarkan sih kita } \\
\text { sedikit sekali ya minim sekali karena } \\
\text { kita selalu membawa barang dari } \\
\text { rumah terkadang, bawa ongkos yang } \\
\text { secukupnya dan untuk pergi juga kita } \\
\text { numpang dengan orang kalaupun naik } \\
\text { angkutan umum kan cuman bayar } \\
2000 \text { rupiah saja }\end{array}$ \\
\hline \multirow{2}{*}{9} & \multirow{2}{*}{$\begin{array}{c}\text { Apa dampak } \\
\text { negatif dari } \\
\text { penggunaan } \\
\text { media digital } \\
\text { bagi } \\
\text { komunitas } \\
\text { Muslim } \\
\text { Backpacker } \\
\text { Jakarta }\end{array}$} & Informan 3 & $\begin{array}{l}\text { Menurut saya dampak yang didapati } \\
\text { dari penggunaan media digital cukup } \\
\text { banyak ya, seperti waktu untuk } \\
\text { berkumpul sama teman-teman jadi } \\
\text { terganggu dengan ponsel masing- } \\
\text { masing, terus juga jadi lebih mudah } \\
\text { buat pergi kemana-mana jadi kurang } \\
\text { ada tantangannya gitu }\end{array}$ \\
\hline & & Informan 4 & $\begin{array}{l}\text { Kalau menurut saya sendiri } \\
\text { penggunaan media digital tidak cocok } \\
\text { dengan komunitas kami ya pasti akan } \\
\text { membuat kami jauh dari beribadah } \\
\text { juga kurang fokus, sama jadi lebih } \\
\text { banyak mainin media sosial seperti } \\
\text { Instagram, Facebook dan lain } \\
\text { sebagainya }\end{array}$ \\
\hline \multirow[b]{2}{*}{10} & \multirow{2}{*}{$\begin{array}{c}\text { Apa dampak } \\
\text { positif dari } \\
\text { penggunaan } \\
\text { media digital } \\
\text { bagi } \\
\text { komunitas } \\
\text { Muslim } \\
\text { Backpacker } \\
\text { Jakarta }\end{array}$} & Informan 3 & $\begin{array}{l}\text { Dampak positifnya mungkin banyak } \\
\text { ya, seperti tadi mempermudah dalam } \\
\text { melakukan segala urusan, jadi mudah } \\
\text { untuk cari transportasi yang } \\
\text { diinginkan, dan juga lebih mudah } \\
\text { dalam melakukan pencarian kalau } \\
\text { salah satu anggota tersesat }\end{array}$ \\
\hline & & Informan 4 & $\begin{array}{l}\text { kalau menurut saya dampak positif } \\
\text { dari media digital sangat banyak ya, } \\
\text { itu mempermudah mereka dalam } \\
\text { melakukan perjalanan jadi mereka } \\
\text { bisa booking transportasi yang } \\
\text { mereka mau, tidak usah repot repot } \\
\text { untuk memberhentikan angkutan atau } \\
\text { menebeng dengan truk yang ada, } \\
\text { yang malah membuat kita tidak tentu } \\
\text { kapan berangkatnya tidak sesuai } \\
\text { dengan apa yang kita rencanakan } \\
\text { walaupun dengan memberhentikan }\end{array}$ \\
\hline
\end{tabular}




\begin{tabular}{|l|l|l|l|}
\hline & & $\begin{array}{l}\text { angkutan lebih murah biayanya } \\
\text { namu hal tersebut malah membuat } \\
\text { resah masyarakat setempat, saya } \\
\text { mengakui hal tersebut namun } \\
\text { namanya backpacker susah senang } \\
\text { kita hadapi bersama. }\end{array}$ \\
\hline
\end{tabular}

Sumber: Dokumentasi Peneliti

1. Untuk dampak positif, mempermudah komunitas backpacker dalam melakukan perjalanan, dengan adanya aplikasi yang membantu pemesanan tiket pesawat, bus dan hotel. Biaya yang dihasilkan dari penggunaan media digital dapat mengurangi pengeluaran untuk grup besar karena terdapat discount dan promo yang diberikan oleh aplikasi penyedia jasa akomodasi terhadap komunitas backpacker.

2. Untuk dampak negatif, beberapa anggota komunitas lebih cenderung sibuk dengan ponsel atau media sosial yang membuat kurangnya komunikasi pada anggota komunitas yang lain.

Dari hasil wawancara menunjukkan bahwa dampak yang lebih besar dirasakan oleh komunitas backpacker yaitu dampak positif dari penggunaan media digital karena dapat membantu dalam menangangi masalah yang dihadapi oleh komunitas backpacker.

\section{Simpulan}

Penelitian ini menyimpulkan bahwa komunikasi merupakan proses di mana seseorang maupun sekelompok orang menciptakan interaksi dengan menggunakan informasi yang saling berhubungan dengan lingkungan sekitar. Kedua, dampak negative merupakan dampak buruk yang dihasilkan dari penggunaan media digital oleh komunitas backpacker, dengan melihat dari pengalaman sehingga dapat mengetahui sisi negatif yang didapatkan. Terakhir, dampak positif merupakan dampak baik yang dihasilkan dari penggunaan media digital oleh komunitas backpacker, dengan mengetahui pengalaman anggota komunitas dengan adanya aplikasi media digital dan media sosial yang dapat membantu komunitas backpacker Jakarta dalam melakukan sebuah perjalanan pariwisata.

\section{Ucapan Terima Kasih}

Penulis mengucapkan terimakasih yang sebesar-besarnya kepada pembimbing dan para dosen Fakultas Ilmu Komunikasi Universitas Tarumanagara yang telah memberikan ilmu yang bermanfaat kepada penulis.

\section{Daftar Pustaka}

Abdul Kadir. (2003). Konsep dan Tuntunan Praktis Basis Data. Yogyakarta: Andi. Abdul Kadir. (2003) Pengenalan Sistem Informasi. Yogyakarta: Andi.

Sugiyono. (2012). Memahami penelitian kualitatif. Bandung: ALFABETA.

Sukendro, Genep Gregorius dan Rusdi, Farid. (2018). Analisis Industri Kreatif Dalam Memanfaatkan Identitas Kota Melalui Media Baru. Universitas Tarumanagara. 